\title{
The Pre-crisis Exchange Rate Management and External Balance in Selected East Asian Countries
}

\section{国土交通省 Hiroyuki Taguchi*}

Exchange rate management is one of the central issues of macroeconomic policies. Since the postwar period, there has been a long-term debate over the merits of fixed versus floating exchange rates. The debate, which is typically framed in terms of the trade-off between credibility and flexibility, has gone through several swings of the pendulum. Recently, the debate on exchange rate regimes has become focused on whether or not the intermediate regimes such as target zones, crawling and basket pegs are vanishing, in other words, whether or not exchange rate regimes are moving to a corner solution with the "hard peg" or the "free float". So far, no clear consensus has been reached.

The 1997-98 Asian crises have refocused attention on exchange rate management of East Asian countries. Most views expressed criticize the pre-crisis US dollar-pegged-rate regime as one of the causes of the crisis. It is said that this regime induced short-term external over- borrowing and caused the appreciation of real exchange rates with the loss of competitiveness. The question also arises as to whether, after the crisis, the East Asian countries are simply returning to the pre-crisis US dollar standard, or whether they have learned a lesson from the crisis and are finding another path to follow.

This article focuses on the exchange rate management of the selected East Asian countries, evaluates the pre-crisis dollar peg system from the viewpoint of such external balances as capital flow and trade, and examines the post-crisis exchange rate management. The main findings are as follows: 1) the dollar peg system had induced massive capital inflows through significantly large super risk premium against the US; 2) the dollar peg system had deteriorated trade balances through significantly large appreciation of real effective exchange rate; 3) as an alternative exchange rate management, the inflation-slid management, rather than the basket pegging, had

* Director, Ministry of Land, Infrastructure and Transport, Taguchi-h2k9@mlit.go.jp, T0A7G1U0@aol.com. 
been more preferable than the simple dollar peg system from the viewpoints of stabilizing both capital inflow and trade balance; 4) in the post-crisis exchange rate management, some East Asian countries have come to care more about the factor of the inflation slide in addition to the US dollar linkage. We speculate that they may have learned the lessons that the Asian crisis was partly caused by the simple US dollar peg regime accompanied by massive capital inflows and worsening trade balance. The strategic implication of the findings is the importance of inflation slide in the exchange rate management in the emerging East Asian economies. 